\title{
ANALISIS SEMIOTIKA IKLAN GOJEK \#GAKPAKELAMA DAN IKLAN GRAB \#ANTINGARET PADA LAYANAN TRANSPORTASI ONLINE DI INDONESIA
}

\author{
Betha Almanfaluthi ${ }^{1}$, Juniar ${ }^{2}$ \\ ${ }^{1,2}$ Desain Komunikasi Visual, Fakultas Ilmu Komputer dan Desain, Institut Teknologi dan Bisnis Kalbis \\ betha.almanfaluthi@kalbis.ac.id ${ }^{1}$, juniar@kalbis.ac.id²
}

\begin{abstract}
Abstrak
Gojek dan Grab adalah salah satu perusahaan jasa online terbesar di Indonesia. Baik Gojek maupun Grab memiliki banyak jenis jasa yang ditawarkan, akan tetapi transportasi menjadi jasa utama keduanya. Kondisi jalanan di kota-kota besar di Indonesia khususnya Jakarta yang sering mengalami kemacetan, menjadikan kendaraan roda dua menjadi alternatif berkendara yang populer. Sebagai dua perusahaan transportasi online yang memiliki layanan dan sasaran konsumen yang sama sehingga dalam membuat iklan Gojek dan Grab ada kecenderungan memiliki pesan yang sama dan tema yang mirip namun juga terlihat berbeda. Kajian ini bertujuan untuk menganalisa makna iklan kampanye \#gakpakelama oleh Gojek dan \#antingaret oleh Grab dengan mengurai tanda-tanda visual untuk melihatkan perbedaan antar kedua layanan transportasi online tersebut. Penelitian dilakukan dengan metode analisis isi yang dikombinasikan dengan pendekatan semiotika Roland Barthes yang menganalisis perluasan makna tanda. Dari hasil analisis didapatkan bahwa pengguna transportasi online digambarkan sebagai pekerja kantoran usia muda yang butuh solusi berupa layanan transportasi online yang siap kapan pun sebagai sebuah solusi yang dapat membantu orang-orang berjuang menghadapi kehidupan pekerjaan di kota besar terkait waktu.
\end{abstract}

Kata Kunci: analisis isi, gojek, grab, iklan, semiotika

\begin{abstract}
Gojek and Grab are some of the largest online service companies in Indonesia. Both Gojek and Grab have various types of services, but transportation is the primary service. Road conditions in big cities in Indonesia, especially Jakarta, often experience traffic jams so that two-wheeled vehicles are a popular alternative to driving. As two online transportation companies have the same services and target consumers, Gojek and Grab advertisements tend to have the same message and similar themes but also look different. This study purpose to analyze the meaning of the \#gakpakelama by Gojek and \#antingaret by Grab campaign advertisements by parsing visual signs to show the distinctions between the two online transportation services. The research was conducted using the content analysis method combined with the semiotic approach of Roland Barthes that analyzed the expansion of the meaning of the sign. From the analysis of the results, it was found that online transportation users are described as young office workers who need solutions in the form of online transportation services that are ready at any time as a solution that can help people struggle with working life in big cities related to time.
\end{abstract}

Keywords: campaign, content analysis, gojek, grab, semiotic 


\section{PENDAHULUAN}

Indonesia memiliki beberapa kota yang dikenal dengan kemacetannya, salah satunya tentu Jakarta yang merupakan salah satu kota dengan tingkat kemacetan yang sangat tinggi. Hal ini menjadikan kendaraan roda dua atau motor yang lebih fleksibel menghadapi kemacetan menjadi kendaraan alternatif yang banyak digunakan. Setiap waktu kita dapat melihat bagaimana motor memenuhi jalanan dari pagi hari hingga malam. Motor adalah salah satu kendaraan umum favorit bagi mereka yang ingin bepergian secara praktis tanpa harus repot memikirkan tempat parkir. Kendaraan umum berupa motor ini biasa disebut ojek. Di Jakarta banyak yang menjadikan ojek sebagai mata pencaharian mereka. Ojek merupakan salah satu produk budaya yang berkembang saat ini. Sebuah produk budaya dalam perkembangannya itu akan ada nilainilai budaya yang bersinggungan dan bahkan saling meniadakan (Khamadi \& Senoprabowo, 2018). Hal tersebut tidak dapat dipungkuri untuk era perkembangan teknologi sekarang ini.

Kehadiran ojek online seperti Gojek dan Grab sangat memudahkan penumpang untuk mencari ojek. Penumpang tidak perlu mencari di jalan untuk mendapatkan ojek. Cukup dengan menggunakan aplikasi penumpang dapat menunggu di tempat untuk dijemput. Sistem pemesanan ini mengadaptasi cara pemesanan taksi via telepon, yaitu calon penumpang menelepon perusahaan taksi dari rumah untuk memesan taksi. Lalu perusahaan taksi akan menghubungi taksi yang terdekat dengan lokasi penjemputan. Calon penumpang tinggal menunggu dijemput. Seiring dengan perkembangan teknologi informasi dan komunkasi, proses pemesanan ojek menjadi jauh lebih mudah. Dengan aplikasi yang ada penumpang tidak lagi perlu menghubungi perusahaan angkutan umumnya namun akan langsung terhubung dengan pengemudi ojek.

Saat ini ada dua perusahaan ojek online besar di Indonesia, yaitu Gojek dan Grab. Gojek merupakan perusahaan yang awalnya merupakan startup yang salah satu pendirinya adalah Nadiem Makarim yang saat ini menjabat sebagai menteri Pendidikan dan Kebudayaan, sedangkan Grab merupakan perusahaan ojek online yang berasal dari Malaysia. Grab telah tersebar di beberapa negara di Asia Tenggara. Grab menjangkau 338 kota yang tersebar di 8 (delapan) negara sehingga ini menjadikannya sebagai layanan dengan jangkauan terluas di Asia Tenggara (Grab Indonesia, 2019). Begitu juga Gojek, telah merambah ke beberapa negara tetangga seperi Vietnam dan Thailand.

Dengan kondisi jalanan Jakarta yang masih memiliki tingkat kemacetan tinggi sampai saat ini, ketepatan waktu masih menjadi momok bagi para pengguna jalan. Waktu kedatangan seseorang ke suatu tempat kadang sulit diestimasi dan tidak jarang para pengguna jalan harus berangkat jauh lebih awal agar tidak terlambat tiba di tujuan. Kondisi ini menjadi insight bagi perusahaan ojek online dalam menentukan strategi kampanye mereka untuk merangkul calon konsumen untuk menggunakan jasa mereka. Terlebih sistem transportasi umum adalah salah satu orientasi yang difokuskan untuk dikembangkan pemerintah (Subarkah, 2019). Sebagai dua perusahaan transportasi online yang memiliki layanan dan sasaran konsumen yang sama tentu satu sama lain merupakan kompetitor. Sehingga dalam iklan-iklan Gojek dan Grab ada kecenderungan 
memiliki pesan yang sama terlebih keduanya mengusung tema mirip pada kampanye yang berjalan hampir bersamaan ini.

Berdasarkan uraian di atas maka penelitian ini akan mengkaji bagaimanakah analisis semiotika iklan kampanye \#gakpakelama oleh gojek dan \#antingaret oleh Grab?. Penelitian ini melakukan kajian melalui tanda-tanda visual yang didukung tanda verbal pada iklan-iklan kampanye \#gakpakelama oleh Gojek dan \#antingaret oleh Grab. Penelitian ini bertujuan untuk menganalisa semiotika iklan-iklan kampanye \#gakpakelama oleh Gojek dan \#antingaret oleh Grab agar mengetahui pesan secara khusus yang membedakan keunggulan masing-masing layanan transportasi online. Sebagai dua perusahaan transportasi online yang memiliki layanan dan sasaran konsumen yang sama sehingga dalam membuat iklan Gojek dan Grab ada kecenderungan memiliki pesan yang sama dan tema mirip tetapi terlihat berbeda juga dengan tetap memperlihatkan nilai budaya Indonesia ditengah modernitas dalam bentuk yang baru. Masyarakat Indonesia sering kali terjebak dalam persoalanpersoalan kearifan lokal yang tersisihkan oleh modernitas (khamadi \& Senoprabowo, 2021). Penelitian ini mengacu pada penelitian semiotika lain dari Muqoddas \& Hasyim (2016), Suryaningtyas, Nugroho, Cahyono, Nababan, \& Santosa (2019) dan Sulistiyawati (2016) tentang pengungkapan makna menggunakan kajian semiotika tetapi belum ada yang mengungkapkan makna semiotika pada iklan Gojek dan Grab sehingga hal tersebut menjadi kebaharuan penelitian ini.

\section{METODE PENELITIAN}

Penelitian ini dilakukan dengan metode analisis isi yaitu penelitian yang dilakukan dengan cara mengurai konten sebuah informasi yang pada penelitian ini yaitu iklan-iklan Gojek dan Grab. Analisis isi banyak diterapkan di penelitian ilmu komunikasi. Dalam ranah visual, analisis isi pesan pun dapat digunakan. Analisis isi adalah cara untuk mengidentifikasi sebuah pesan dengan mengurai unit-unit analisis di dalamnya untuk mengetahui karakteristik isi komunikasi (Rose, 2016). Analisis isi dapat digunakan bersama dengan pendekatan semiotika yang akan menginterpretasi makna dari karakteristik yang diurai dalam analisis isi (Berger, 2018). Dalam analisis isi diperlukan lembar coding yang digunakan untuk mendapatkan kategori-kategori unit analisis pembangun visual. Analisis isi merupakan penganalisaan sebuah teks secara terstruktur untuk mencari makna dari sebuah komunikasi dengan membedah pola-pola yang disusun oleh unit-unit di dalam teks tersebut. Metode ini menggunakan teknik pengkodean simbol-simbol oleh analis dengan mencatat unit-unit analisis yang digunakan untuk menyampaikan pesan (Berger, 2018).

Tanda-tanda visual yang muncul sebagai unit analisis dalam iklan akan dikaji dengan pendekatan semiotika Roland Barthes untuk mendapatkan interpretasi bagaimana lingkungan perkotaan dan konsumen transportasi online digambarkan lewat iklan. Dalam penelitian ini pengumpulan data dilakukan dengan cara mengumpulkan data visual berupa iklan video kampanye \#gakpakelama oleh Gojek dan \#antingaret oleh Grab. Dalam penelitian ini, kategori unit analisis akan ditelaah terlebih dahulu yang kemudian akan menjadi unit yang akan dikaji. Kemudian mengumpulkan data berupa 
iklan-iklan kampanye \#gakpakelama dan \#antingaret. Selanjutmya mengidentifikasi unsur-unsur pembentuk visual pada tiap iklan. Lalu melakukan pengkategorian berdasarkan unsur-unsur dominan pembentuk makna. Menginterpretasi makna semiotika pada kedua iklan kampanye.

Pada awalnya setiap tanda selalu memperoleh pemaknaan pertama yang memiliki makna umum karena dilihat maknanya secara denotasi, Barthes menyentuhnya dengan sistem primer. Selanjutnya makna mengalami proses perluasan, proses kognitif yang berangkat berasal dari dampak budaya. Ini merupakan sistem sekunder. Analisa iklan menerapkan teori sistem sekunder yang meluaskan makna yang juga disebut konotasi. Proses ini menghasilkan makna lain, dari satu tanda bisa memiliki lebih dari satu makna (Hood, 2014). Munculnya makna konotasi beragam yang berangkat dari satu makna denotasi sangat dimungkinan karena pengaruh latar belakang budaya tempat tanda tersebut berada (Crow, 2011).

\section{HASIL DAN PEMBAHASAN}

\subsection{Kampanye Gojek dan Grab}

Dalam kurun waktu yang bersamaan, Gojek dan Grab melakukan kampanye yang mirip. Kampanye yang dilakukan dua perusahaan layanan transportasi ini sama-sama ingin menyampaikan adding value yang telah diusung oleh ke dua perusahaan transportasi online ini. Salah satu cara adding value yang dapat dilakukan oleh sebuah brand adalah menghadirkan inovasi (Shimp, 2003). Inovasi terbaru terbaru oleh dua perusahaan transportasi online ini ada pada fitur dalam aplikasi mereka. Fitur yang dimaksud adalah fitur yang bertujuan untuk mempercepat bertemunya pengemudi dengan calon penumpang. Gojek dengan kampanye \#GakPakeLama mengeluarkan beberapa fitur baru bagi pengguna GoRide dan GoCar yakni fitur titik jemput terdekat dan titik jemput dengan foto.

Fitur titik jemput terdekat memberikan calon penumpang pilihan beberapa titik di sekitar posisi dia berada. Calon penumpang tinggal memilih salah satu titik tersebut sehingga memudahkan pengemudi mencari lokasi penjemputan. Fitur berikutnya yaitu titik jemput dengan foto pada dasarnya mempunyai fungsi yang sama dengan fitur titik jemput terdekat namun informasi titik jemput dilengkapi dengan foto lokasi titik-titik yang dimaksud. Ini bertujuan agar pengemudi dapat betul-betul memastikan lokasi penjemputannya sudah benar sesuai dengan lokasi yang ada di foto.

Lalu Grab dengan kampanye \#AntiNgaret juga menyediakan fitur yang bisa dibilang sama dengan fitur titik jemput terdekat milik Gojek yaitu fitur Venues. Fitur ini memandu calon penumpang untuk menentukan titik penjemputan yang dilengkapi dengan foto lokasi. Data Titik-titik ini didapatkan dari hasil identifikasi oleh tim khusus yang melakukan pemetaan. Ini bisa dilihat bahwa tujuan dari fitur ini sama dengan fitur yang ada pada Gojek yaitu memudahkan proses bertemunya pengemudi dan calon penumpang. 
Kampanye yang dilakukan dua perusahaan layanan ojek online ini berlangsung di waktu yang hampir bersamaan yaitu di pertengahan hingga akhir 2019. Fitur-fitur yang disediakan pada aplikasi layanan ojek online ini tentunya menjadi salah satu fitur unggulan yang ada. Hal ini mengingat pengalaman banyak orang dalam menunggu kedatangan ojek online. Tidak jarang ketika penumpang ditanya ingin dijemput di mana merasa bingung bagaimana menjelaskan lokasi tempat mereka ingin dijemput. Pertanyaan yang kerap muncul dalam hati ketika terjadi situasi seperti itu adalah "ini di mana ya?". Lalu ketika tidak dapat menjelaskan biasanya penumpang bertanya kepada orang-orang yang ada di sekitar mereka dan meminta tolong untuk mejelaskan lokasi tempat mereka menunggu. Penjelasan lokasi biasanya dilakukan dengan mengirimkan pesan atau pun dengan cara menelepon. Tetapi terkadang dengan penjelasan yang sudah diberikan pun pengemudi masih kesulitan menemui calon penumpang dikarenakan interpretasi pengemudi berbeda dengan maksud penjelasannya.

Selain sulit menjelaskan lokasi, proses bertemu antara pengemudi dan calon penumpang juga bisa menjadi lama atau terkendala dikarenakan pengemudi tiba di titik jemput yang salah. Contoh yang terjadi adalah ketika penumpang ingin dijemput di sebuah pusat perbelanjaan. Seperti yang kita ketahui sebuah pusat perbelanjaan yang besar memiliki lebih dari satu lobi. Jika tidak menyebutkan secara detail ada di lobi mana atau salah menyebutkan area lobi maka ada kemungkinan pengemudi tiba di titik jemput yang salah. Sehingga penumpang terpaksa harus menunggu agak lebih lama hingga pengemudi dapat tiba di titik jemput yang tepat. Proses menunggu penjemputan ini tentu berpengaruh terhadap berapa lama penumpang dapat tiba di lokasi tujuan dihitung dari penumpang memesan ojek online. Kampanye oleh dua perusahaan layanan transportasi online yang dibahas pada penulisan ini adalah fokus kepada fitur yang telah dijelaskan di atas yaitu kecepatan pengemudi tiba di lokasi penjemputan. Komunikasi yang disampaikan pada kampanye bertujuan menunjukkan bahwa kecepatan perjalanan ojek online juga dipengaruhi oleh kecepatan pengemudi dalam menjemput penumpang.

Untuk judul kampanye, kedua kampanye ini menggunakan istilah yang sudah umum dikenal dan sering digunakan dikalangan masyarakat Indonesia saat membicarakan halhal yang berhubungan erat dengan waktu. "Gak pake lama" adalah istilah yang sering digunakan sebagai pesanan tambahan saat hendak memesan atau meminta sesuatu dan butuh waktu untuk menunggu. Saat-saat menunggu memang merupakan saat yang tidak mengenakkan jika waktu yang terpakai untuk menunggu tergolong lama. Oleh karena itu istilah "gak pake lama" kerap digunakan sebagai tambahan pesanan atau permintaan yang dijadikan pengingat agar pesanan atau permintaannya dipenuhi dengan segera.

Untuk kampanye oleh Grab yang menggunakan istilah "anti ngaret" juga menggunakan istilah tersebut karena erat kaitannya dengan waktu, lebih tepatnya waktu kedatangan seseorang. Kata ngaret berasal dari kata karet, sebuah benda yang memiliki sifat melar atau dapat melonggar ketika ditarik. Sifat karet ini dimetaforakan dengan ketidaktepatan seseorang hadir pada waktu yang telah ditentukan atau meleset dari 
waktu yang sudah direncanakan. Kata "ngaret" dipilih karena ini sudah dikenal oleh masyarakat Indonesia sendiri sebagai salah satu kebiasaan buruk yang dimiliki orangorang Indonesia. Ini adalah sebuah fenomena yang tentu tidak semua melakukan hal ini tapi tak bisa dipungkiri memang sering terjadi apalagi di daerah perkotaan besar dengan kondisi jalanan yang ramai dipadati kendaraan pada jam-jam tertentu.

Dari nama yang digunakan untuk nama kampanye masing-masing dapat dilihat bahwa Gojek dengan kampanye \#GakPakeLama ingin menegaskan bahwa jika memesan Gojek maka untuk menunggu pengemudi gojek tidak perlu lama. Begitu juga dengan Grab dengan kampanye \#AntiNgaret lewat kampanye ini ingin menyampaikan bahwa jika memesan Grab maka pengemudi siap untuk tiba di lokasi tidak terlambat.

\subsection{Iklan Video Gojek}

Berikut ini akan diurai dan ditelaah iklan video pada kampanye yang dilakukan masingmasing. Iklan video Gojek untuk kampanye \#GakPakeLama yang dikaji adalah versi Kisah Horor di Hari Pertama Ngantor. Suara yang ada pada iklan ini adalah suara musik dan suara voice over yang mewakilik suara dari pemeran utama. Pada iklan ini jika terdengar suara pemeran utama maka akan selalu dilengkapi dengan subtitle. Shot diawali dengan suasana gelap pada sebuah ruangan kantor karena beberapa lampu telah dipadamkan dan hanya menyisakan sedikit lampu yang menyala. Setting waktunya memang dibuat telah melewati jam kerja sampai larut malam sehingga tampak sepi tidak ada lagi karyawan lain selain pemeran utama.

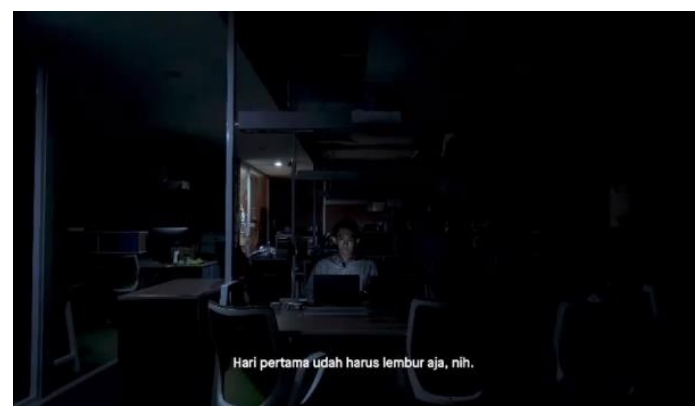

Gambar 1. Potongan Adegan Iklan Gojek 1

[Sumber: Instagram Gojek]

Adegan pada shot tersebut memperlihatkan si pemeran utama sedang mengerjakan pekerjaan menggunakan laptop di sebuah meja menghadap ke kamera. Mejanya berukuran besar yang digunakan bersama-sama dengan karyawan lain, bukan tipe meja cubicle seperti yang tampak di sekelilingnya. Ini memberikan makna bahwa pemuda yang menjadi pemeran utama ini tergolong sebagai karyawan di level staff. Pada saat adegan awal ini juga tertera subtitle berwarna putih bertuliskan "Hari pertama udah harus lembur aja, nih.".

Makna denotasi pada tampilan ini adalah adanya seorang pemuda laki-laki yang sedang berada di depan laptop di sebuah ruangan gelap dan sepi. Melihat unit-unit visual yang ditampilkan akan muncul konotasi bahwa ini adalah suasana kerja lembur di sebuah 
kantor di sebuah kota. Ini seolah memberikan perluasan makna bahwa kerja di kota besar memiliki tekanan dalam mengejar tengat waktu.

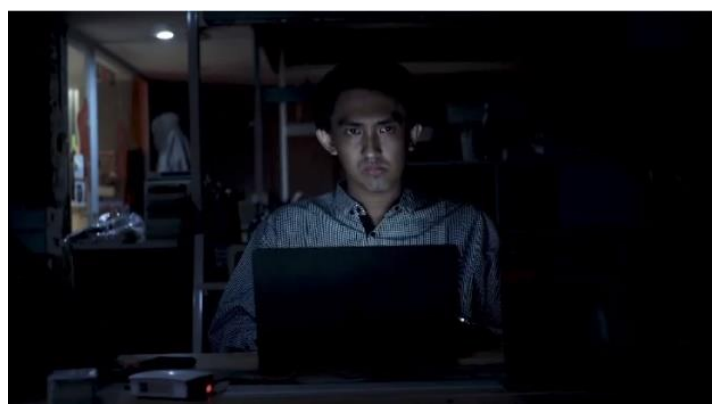

Gambar 2. Potongan Adegan Iklan Gojek 2

[Sumber: Instagram Gojek]

Berikutnya kamera dizoom sedikit memperlihatkan pemuda itu dari jarak yang lebih dekat dan tampak di belakangnya ada obyek berwarna putih bergerak ke arah kiri. Obyek yang terlihat seperti kain berjalan melayang di ruang gelap saat malam hari pada umumnya memiliki makna sesuatu yang menyeramkan. Di Indonesia, visualisasi seperti ini identik dengan sosok makhluk gaib. Setelah sosok di belakang itu menghilang dari frame kamera pemuda itu memegang leher dan tengkuknya. Secara denotasi ini masih mirip dengan yang ada pada shot sebelumnya, namun ada penambahan unit visual yang tampak di belakang pemuda tersebut. Jika ditelaah makna konotasi ini memberikan nuansa mencekam. Di Indonesia situasi dengan visualisasi seperti ini kerap dikaitkan dengan istilah "penampakan".

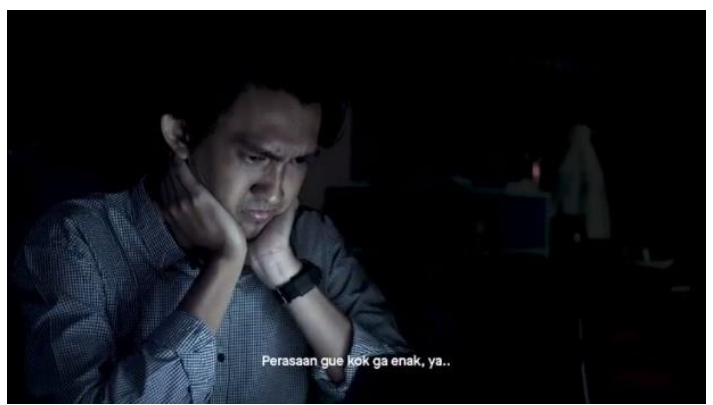

Gambar 3. Potongan Adegan Iklan Gojek 3 [Sumber: Instagram Gojek]

Lalu kamera lebih mendekat lagi ke arah pemuda itu yang masih memegang lehernya dan menatap layar laptop. Di adegan ini tampak kembali sosok dengan mukena putih di belakang yang kali ini ada di sebelah kanan layar. Pada shot ini subtitle berganti menjadi tulisan "Perasaan gue kok ga enak, ya...". 


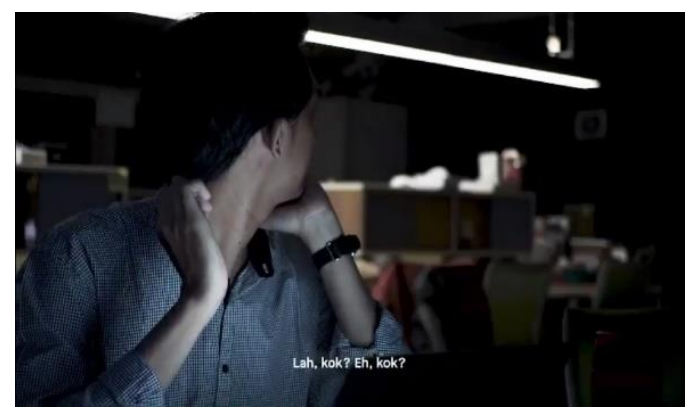

Gambar 4. Potongan Adegan Iklan Gojek 4

[Sumber: Instagram Gojek]

Setelah itu lampu di belakang yang tadinya masih menyala menjadi padam dan selang beberapa detik lampu berkedap-kedip antara nyala dan padam. Pemuda itu terkejut dan melihat kearah belakang. Di adegan ini subtitle berganti menjadi tulisan "Lah, kok? Eh, kok?". Adegan ini mempertegas makna konotasi pada tampilan yang diperlihatkan. Makna denotasi bahwa lampu silih berganti antara nyala dan padam ini tentu berkembang pada makna konotasi bahwa ada energi dari alam gaib atau sering dianggap sebagai ulah usil yang dilakukan sosok makhluk gaib.

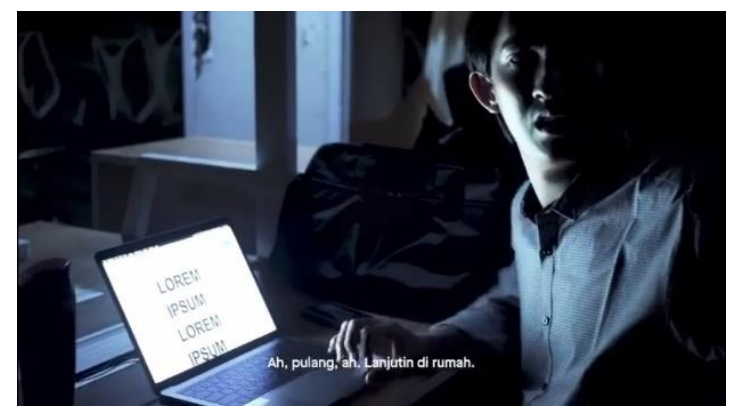

Gambar 5. Potongan Adegan Iklan Gojek 5 [Sumber: Instagram Gojek]

Berikutnya adegan terkejut masih berlangsung dengan arah pengambilan shot berpindah dari arah belakang tempat pemuda tersebut duduk sehingga pemirsa dapat melihat layar laptopnya. Pada shot ini subtitle berganti menjadi tulisan "Ah, pulang, ah. Lanjutin di rumah."
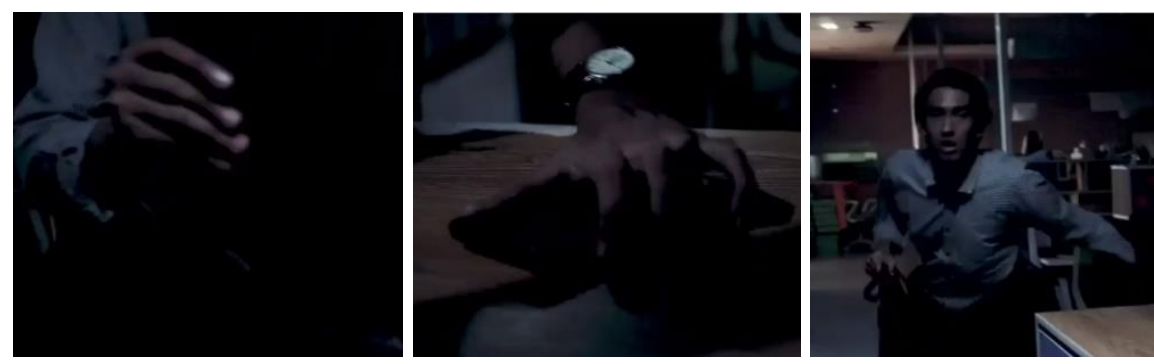

Gambar 6. Potongan Adegan Iklan Gojek 6 [Sumber: Instagram Gojek] 
Kemudian pemuda menutup laptopnya dan memasukkannya ke dalam tas selempang lalu mengambil telepon genggam dan segera keluar dari ruangan sambil berlari.
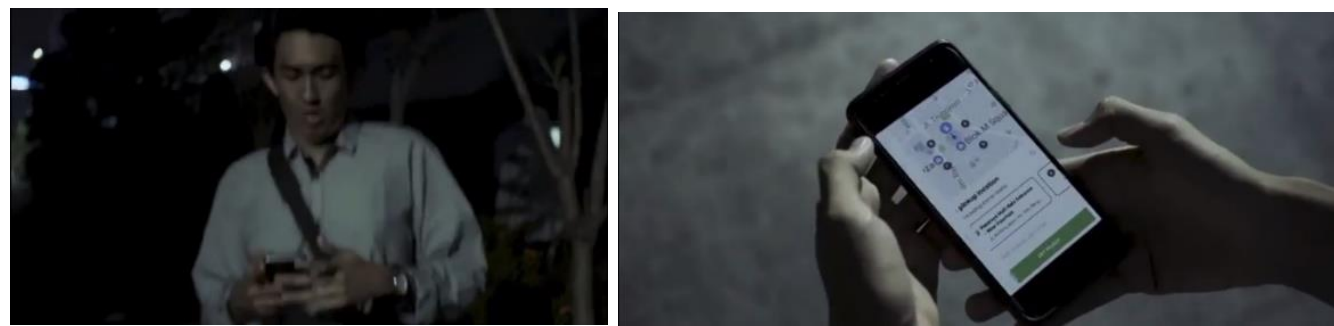

Gambar 7. Potongan Adegan Iklan Gojek 7

[Sumber: Instagram Gojek]

Shot berikutnya terlihat pemuda itu telah sampai di luar gedung kantor dan pemuda itu langsung memesan Gojek. Saat memesan gojek shot memperlihatkan tampilan layar telepon genggam. Pemuda itu diperlihatkan sedang memilih titik jemput.
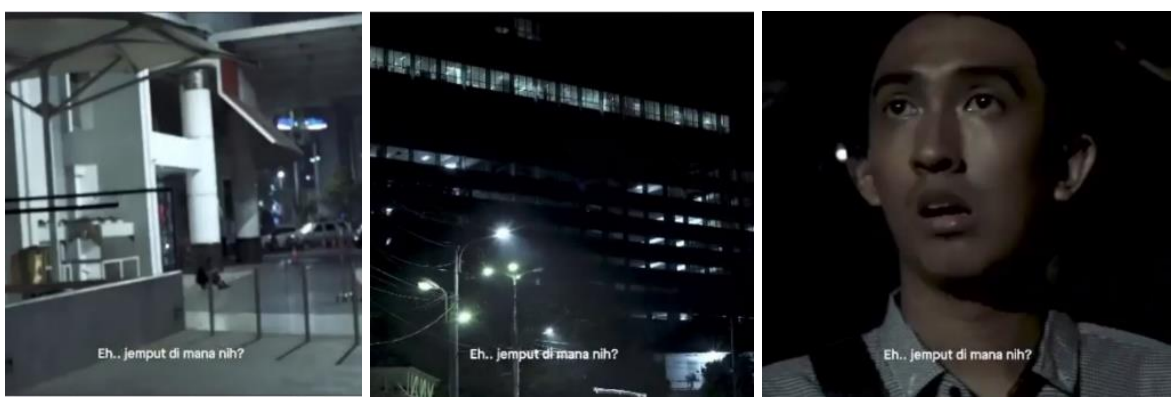

Gambar 8. Potongan Adegan Iklan Gojek 8 [Sumber: Instagram Gojek]

Shot berubah memperlihatkan gestur pemuda itu sedang memastikan di mana posisi dia berada dengan melihat area sekitar. Ekspresi pemudah itu masih terlihat ketakutan. Di shot ini subtitle berganti menjadi tulisan "Eh... jemput di mana nih?".

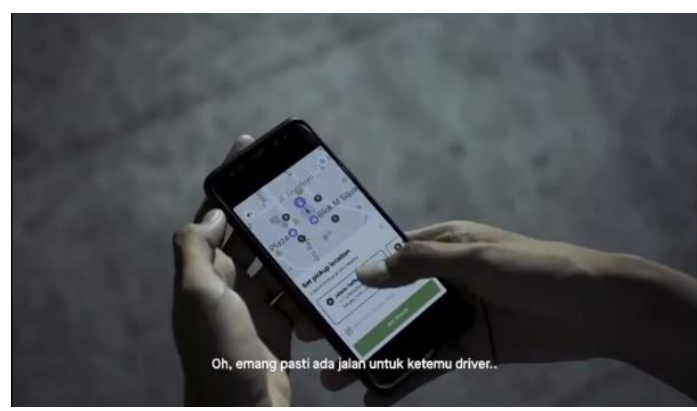

Gambar 9. Potongan Adegan Iklan Gojek 9 [Sumber: Instagram Gojek]

Shot selanjutnya kembali menampilkan layar telepon genggam dan pemuda memilih lokasi dengan menggeser pilihan titik jemput yang kemudian menekan pilihan yang sesuai. Di shot ini subtitle bertuliskan "Oh, emang pasti ada jalan untuk ketemu driver..." lalu berubah menjadi "Gak pake lama!". 


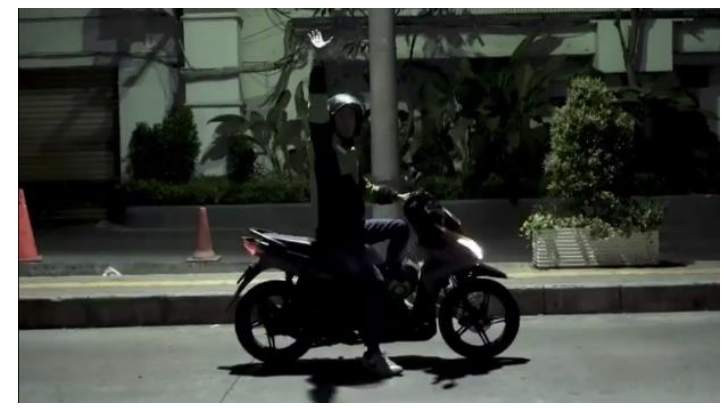

Gambar 10. Potongan Adegan Iklan Gojek 10

[Sumber: Instagram Gojek]

Adegan dilanjutkan dengan shot yang menampilkan sosok pengemudi Gojek yang telah tiba di lokasi dan mengangkat tangan untuk memanggil pemuda itu. Posisi motor terlihat bergerak dari arah kiri ke kanan layar.

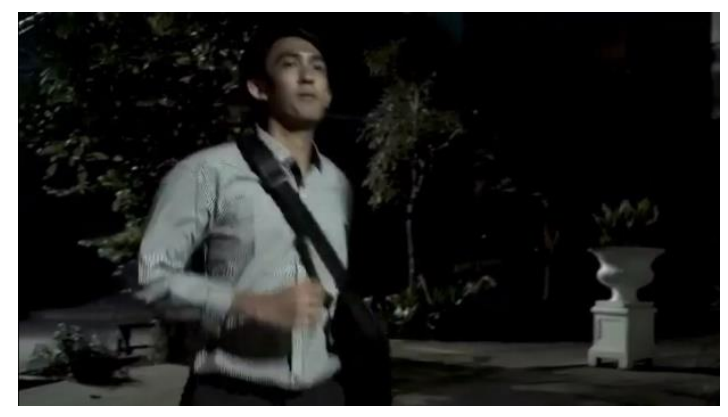

Gambar 11. Potongan Adegan Iklan Gojek 11 [Sumber: Instagram Gojek]

Lalu pemuda itu terlihat berlari mendekati pengemudi. Pengemudi Gojek kemudian memberikan helm. Pemuda mengenakan helm tersebut dan menaiki motor Gojek.

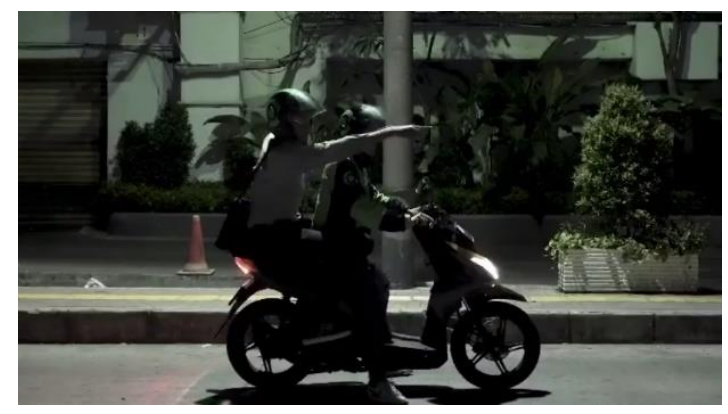

Gambar 12. Potongan Adegan Iklan Gojek 12 [Sumber: Instagram Gojek]

Setelah duduk di motor pemuda itu terlihat menunjuk ke depan mengarahkan pengemudi untuk berjalan menuju arah tersebut lalu motor melaju meninggalkan lokasi penjemputan. Adegan ini menunjukkan bahwa pemuda ini ingin segera pergi dari lokasi dan pengemudi tanpa berlama-lama langsung melaju. 


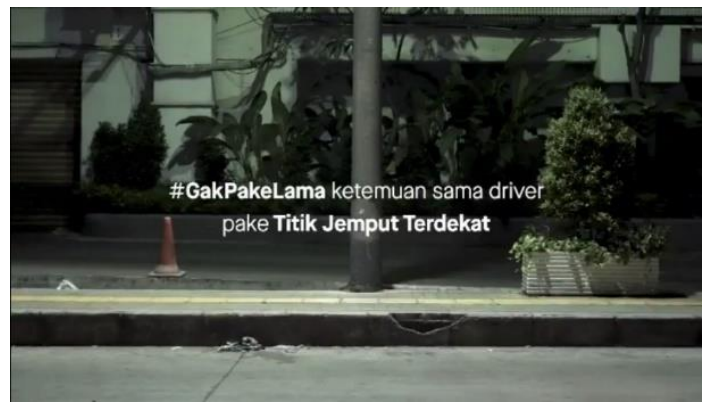

Gambar 13. Potongan Adegan Iklan Gojek 13 [Sumber: Instagram Gojek]

Shot posisi motor bergerak dari tengah ke kanan layar hingga tidak terlihat dari frame kamera. Saat motor melaju muncul tulisan "\#GakPakeLama ketemuan sama driver pake Titik Jemput Terdekat". Ikalm video Gojek ini ditutup dengan menampilkan logo Gojek di latar belakang warna putih. Adegan ini memperlihatkan Kembali suasana sepi di larut malam

\subsection{Iklan Video Grab}

Beralih ke iklan video Grab untuk kampanye \#AntiNgaret. Iklan yang akan dikaji adalah versi berangkat kerja. Peran pemeran utama pada iklan ini mirip dengan iklan Gojek pada bahasan sebelumnya yaitu seorang pemuda pekerja kantoran namun setting waktunya berbeda yaitu di iklan Grab ini diset di pagi hari.

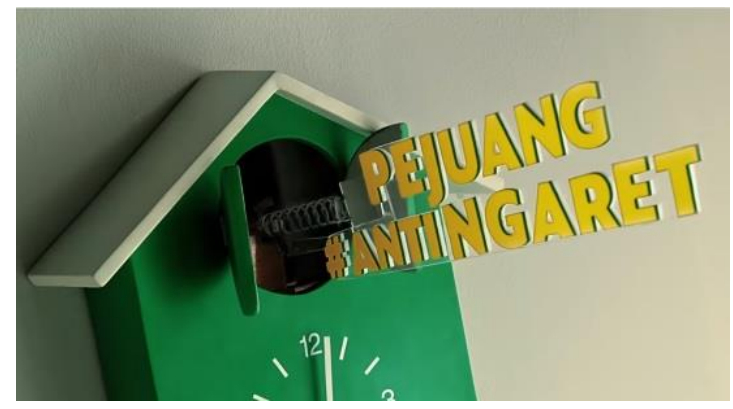

Gambar 14. Potongan Adegan Iklan Grab 1

[Sumber: Youtube Grab Indonesia]

Adegan diawali dengan menampilkan shot jam dinding dengan bentuk jamnya menyerupai jam dinding burung yang ketika berbunyi akan keluar burung. Tetapi dalam video iklan ini ketika alarm berbunyi yang keluar dari jam dinding adalah tulisan PEJUANG \#ANTINGARET dengan huruf kapital semua. Penggunaan jam dinding dengan alarm berbunyi mengandung makna bahwa pemeran yang ada dalam iklan takut telat bangun untuk berangkat kerja. Jam dinding ini juga menegaskan bahwa si pemeran utama, seorang pemuda, harus segera bangun dan tidak bisa mematikan alarm dengan mudah. Jika hanya mengandalkan alarm pada telepon genggam atau jam meja masih ada kemungkinan alarm segera dimatikan atau menggunakan fitur snooze. Mematikan alarm dalam posisi berbaring masih memungkinkan untuk tertidur kembali. Sedangkan alarm pada jam yang menempel di dinding tidak dapat dimatikan ketika orang berada dalam posisi yang masih terbaring di tempat tidur. Penambahan kata "pejuang" 
menunjukkan bahwa untuk bisa tepat waktu butuh usaha yang lebih. Ini merujuk pada situasi jalanan yang kerap menghalangi orang-orang untuk bisa tiba di tempat tujuan dengan cepat.
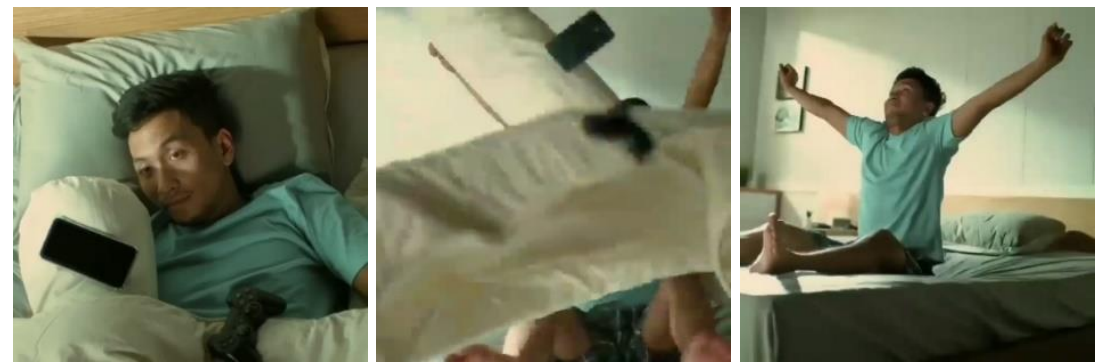

Gambar 15. Potongan Adegan Iklan Grab 2

[Sumber: Youtube Grab Indonesia]

Shot selanjutnya menunjukkan si pemuda ini terbangun dari tidurnya. Terlihat dia tidur sendiri dalam ukuran tempat tidur kecil. Saat terbangun dia meregangkan badannya dan terlihat ada benda-benda di sekitarnya terlempar. Beda-benda yang yang ada antara lain bantal, guling, telepon genggam, serta sebuah joystick permaian konsol. Adanya telepon genggam dan joystick menggambarkan bahwa malamnya sebelum tidur dia bermain game. Efek benda-benda terlempar ini secara hiperbola menunjukkan reaksi si pemeran utama bangun dengan cepat, saking cepatnya benda-benda di sekitarnya terlempar. Dengan reaksi wajah tersenyum memberikan makna konotasi bahwa pemuda ini memiliki semangat di pagi hari. Pakaian yang digunakan saat tidur adalah kaos polos berwarna biru muda ke arah turquois dan celana pendek berwarna biru gelap bergarisgaris putih membentuk motif kotak-kotak.

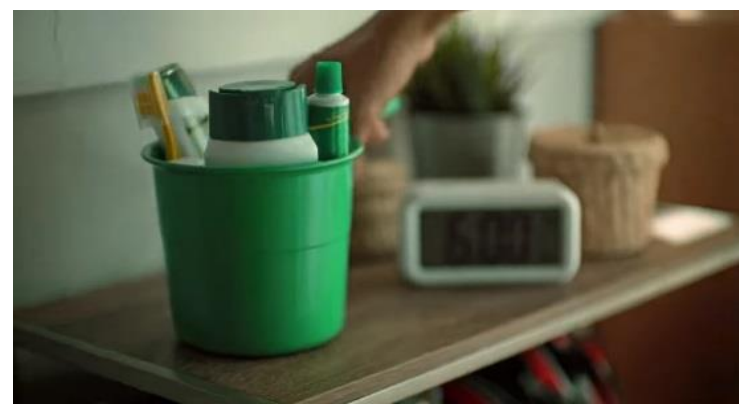

Gambar 16. Potongan Adegan Iklan Grab 3

[Sumber: Youtube Grab Indonesia]

Cerita dalam iklan dilanjutkan dengan shot pemeran utama mengambil gayung yang berisi peralatan mandi yaitu sabun, sampo, pasta gigi, dan sikat gigi yang ada di sebuah meja kecil. Semua peralatan mandi didominasi dengan warna hijau. Di sebelah gayung tersebut terlihat ada jam meja berwarna putih yang juga menunjukkan pukul 6 . Selain itu juga ada pot kecil berisi tanaman berwarna hijau dan dua buah wadah yang terlihat terbuat dari anyaman. Secara konotasi penataan peralatan mandi ini memberikan makna bahwa pemuda ini termasuk orang yang rapi dan teratur. 


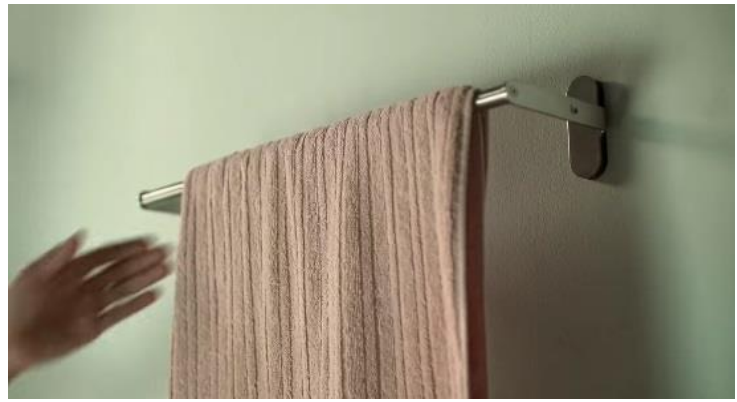

Gambar 17. Potongan Adegan Iklan Grab 4 [Sumber: Youtube Grab Indonesia]

Shot dilanjutkan dengan mengambil handuk yang ada di gantungan yang menempel di salah satu sisi dinding kamar. Setelah mengambil handuk terlihat si pemuda ini keluar kamar dan ternyata pemirsa baru dapat melihat bahwa dia tinggal di sebuah tempat mirip rusun atau kos-kosan bertingkat. Handuk yang tergantung rapi juga mendukung makna konotasi bahwa pemuda ini memiliki pola yang cukup teratur.
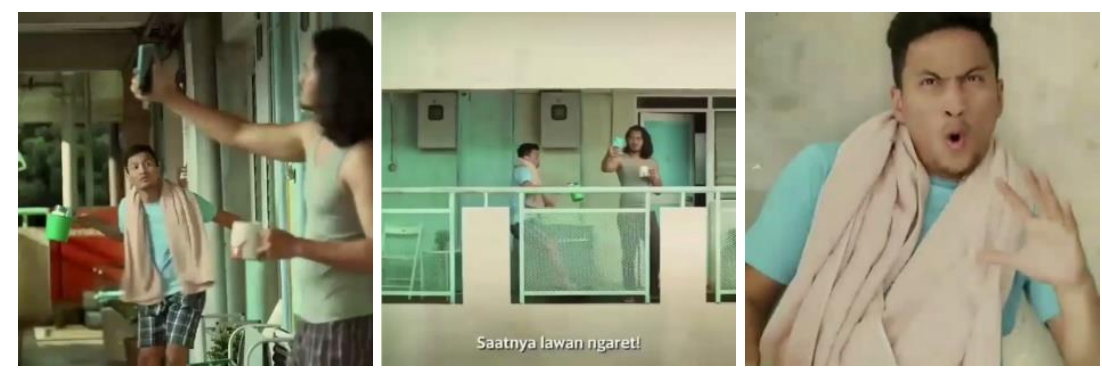

Gambar 18. Potongan Adegan Iklan Grab 5

[Sumber: Youtube Grab Indonesia]

Setelah keluar kamar dia melihat ada orang lain yang juga baru keluar kamar dia tampak terkejut. Orang tersebut adalah seorang laki-laki yang terlihat seumuran dengan pemeran utama berambut panjang hampir sebahu, berkumis dan berjenggot. Pakaian yang digunakan adalah kaos singlet berwarna hijau dan celana panjang dengan warna dan motif yang kurang lebih sama dengan yang dikenakan pemeran utama. Tak lama setelah menunjukkan ekspresi terkejut dia tiba-tiba berlari dan berseluncur di melewati orang tersebut.

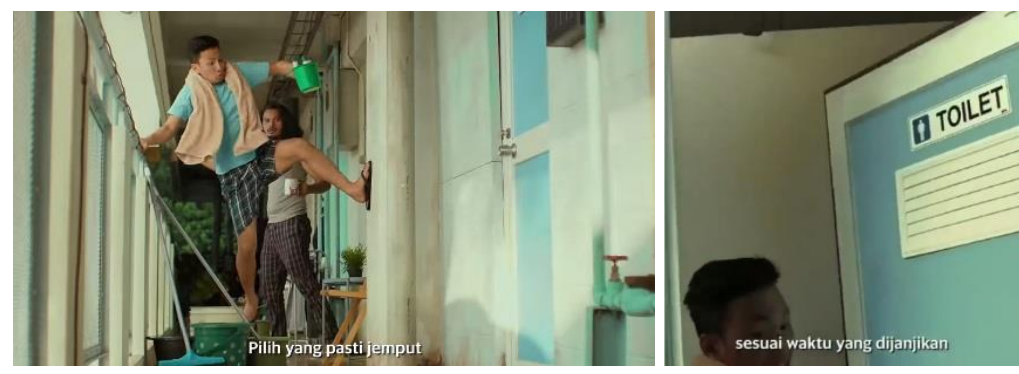

Gambar 19. Potongan Adegan Iklan Grab 6

[Sumber: Youtube Grab Indonesia] 
Setelah melewati orang itu dia lalu melompat untuk menghindari rintangan berupa beberapa ember yang menghadang lajunya. Ternyata dia diperlihatkan sedang terburuburu ingin menuju ke pintu berwarna biru muda bertuliskan toilet. Di situlah tempat dia mandi. Berlari dengan tergesa-gesa ke toilet dikakukan karena takut didahului oleh orang lain yang ingin menggunakan toilet.

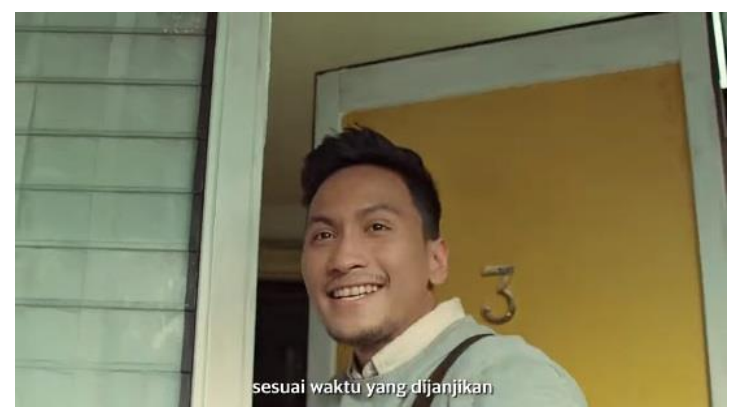

Gambar 20. Potongan Adegan Iklan Grab 7

[Sumber: Youtube Grab Indonesia]

Ketika baru saja masuk ke dalam toilet dan menutup pintu. Tampilan langsung berubah dari pintu toilet menjadi pintu kamar pemeran utama dan langsung terbuka lalu si pemeran utama terlihat telah berganti pakaian menggunakan kemeja putih dirangkap dengan sweater abu-abu.

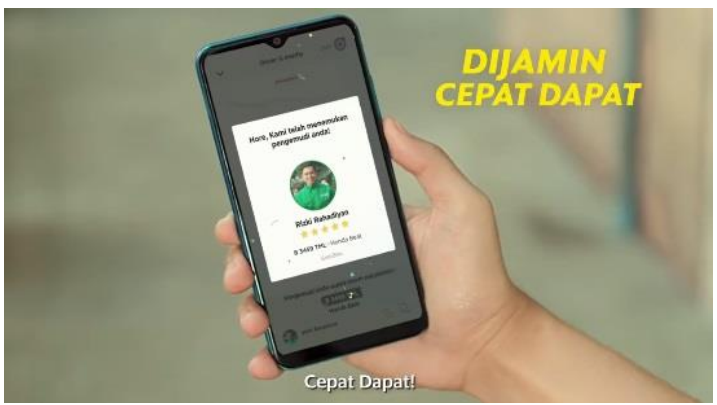

Gambar 21. Potongan adegan iklan Grab 8

[Sumber: Youtube Grab Indonesia]

Dia kemudian terlihat sedang memegang telepon genggamnya dan memesan Grab dan langsung mendapatkan pengemudi. Pada adegan memesan ojek dilengkapi dengan tulisan DIJAMIN CEPAT DAPAT berwarna kuning dengan huruf kapital dan miring (italic). Di bagian bawah juga terdapat subtitle berwarna putih bertulisan Cepat Dapat!

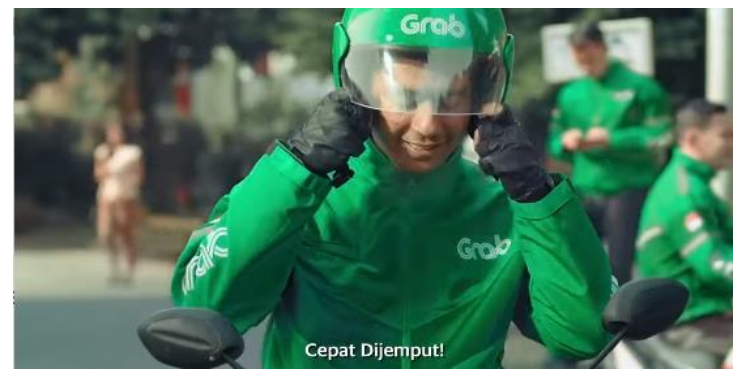

Gambar 22. Potongan Adegan Iklan Grab 9 [Sumber: Youtube Grab Indonesia] 
Adegan dilanjutkan dengan kamera mezoom foto pengemudi yang ada di layar telepon genggam itu. Setelah dizoom foto tersebut berubah menjadi adegan pengemudi yang sedang siap-siap menggunakan helm ingin menjemput.
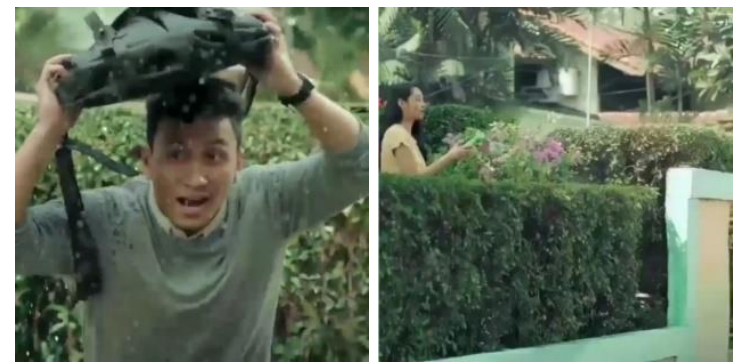

Gambar 23. Potongan Adegan Iklan Grab 10

[Sumber: Youtube Grab Indonesia]

Adegan berpindah kembali ke pemeran utama yang tampak berlari sambil membawa tas selempang hitam yang diletakkan di atas kepalanya karena tersiram rintik-rintik air yang membuat pemirsa mengira kalau keadaan sedang hujan. Tapi ternyata dia terkena rintik-rintik air dari seorang wanita yang terlihat sebaya juga dengan pemeran utama sedang menyiram tanaman di pekarangan rumah.

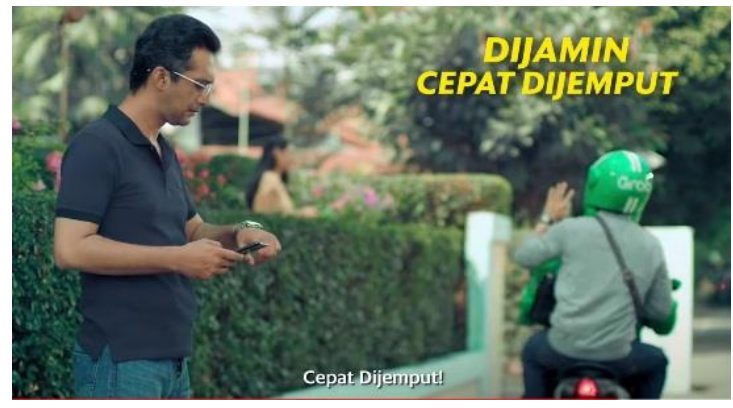

Gambar 24. Potongan Adegan Iklan Grab 11

[Sumber: Youtube Grab Indonesia]

Kemudian tibalah pengemudi Grab tepi jalan depan rumah wanita tadi. Pada shot ini ditambahkan tulisan DIJAMIN CEPAT DIJEMPUT berwarna kuning dengan huruf kapital dan miring (italic). Di bagian bawah juga terdapat subtitle berwarna putih bertulisan Cepat Dijemput! Lalu sambil memakai helm yang diberikan pengemudi dia langsung naik ke motor dan berangkat. Setelah itu kamera bergerak sedikit ke arah kiri untuk memperlihatkan ada seorang bapak yang tampak menunggu seseorang yang kemungkinan besar juga sedang menunggu ojek di titik jemput yang sama. Bapak itu diperlihatkan seolah telah menunggu lama, hal ini terlihat dari ekspresi wajah dan gesturnya saat melihat telepon genggam dan juga jam tangan yang dikenakannya. 


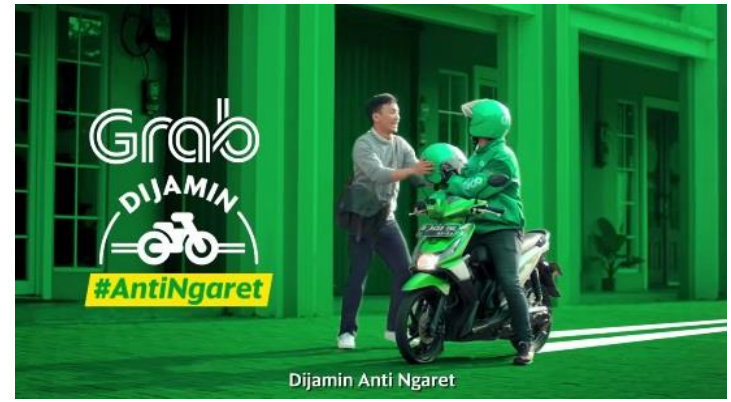

Gambar 25. Potongan Adegan Iklan Grab 12

[Sumber: Youtube Grab Indonesia]

Setelah itu adegan kemudian langsung menampilkan si pemeran utama yang naik Grab tiba di lokasi tujuan dan turun dari motor sambil mengembalikan helm ke pengemudi. Lokasi tujuan tampak seperti ruko perkantoran. Namun, di lokasi tersebut terlihat sepi tidak memperlihatkan orang lain selain dia dan pengemudi Grab. Warna diberi filter hijau sehingga gedung dan lokasi semua terlihat hijau. Ini sekaligus menjadi adegan terakhir yang ditutup juga dengan tampilan logo Grab di sebelah kiri dan di bawah logo itu ada tulisan DIJAMIN \#AntiNgaret dengan ikon sepeda motor di antara tulisan DIJAMIN (di atasnya) dan \#AntiNgaret (di bawahnya).

\subsection{Pemaknaan Tanda Visual Iklan Gojek dan Grab}

Iklan-iklan video yang mendukung kampanye \#GakPakeLama oleh Gojek dan \#AntiNgaret oleh Grab fokus pada informasi fitur baru yang memiliki fungsi yang sama antara yang dimiliki Gojek dan Grab. Setting situasi kehidupan yang ditampilkan dan audiens yang dituju terlihat memiliki demografis yang mirip yaitu diwakili oleh karakter seorang pemuda yang bekerja di perkantoran yang bekerja sesuai jam kerja pada umumnya. Pada Iklan Gojek tampak pemuda tersebut bekerja melampaui jam kerja dan pada iklan Grab terlihat pemuda tersebut sudah bangun jam 6 pagi dan segera berangkat kerja. Pemuda-pemuda yang terlihat pada masing-masing iklan memperlihatkan bahawa mereka adalah sama-sama karyawan di sebuah perusahaan di perkotaan. Sebagai karyawan di perkotaan memang butuh alternatif transportasi yang bisa memudahkan mereka dalam perjalanan pulang pergi bekerja.

Dalam iklan Gojek terlihat menekankan penjemputan yang cepat karena dibantu fasilitas titik penjemputan. Pesan lain yang ingin disampaikan juga adalah siapnya armada gojek di larut malam. Setting outdoor yang diperlihatkan di iklan Gojek tampak suasana komplek perkantoran yang cukup besar dan dapat dilihat bahwa memang itu adalah kawasan perkantoran yang jika di malam hari memang cenderung sepi. Sedangkan pada iklan. Di sini terlihat Gojek ingin menyampaikan bahwa tidak ada yang lain yang siap menjemput hingga larut malam. Dalam iklan Grab terlihat ada pesan bahwa di pagi hari banyak armada Grab yang sudah standby untuk menunggu pesanan layanan antar jemput. Selain itu pada iklan Grab juga membandingkan kecepatan jemput dibanding jika memesan yang lain. 
Editing cut to cut pada masing-masing iklan terlihat berbeda. Di iklan Grab perpindahan dari 1 shot ke shot yang lain terlihat cepat yang memberikan kesan cepat dan sigap serta semangat di pagi hari. Juga mencerminkan kesiapan untuk menghadapi perjalanan ke kantor yang tidak bisa berlama-lama. Ini memberikan makna juga bahwa Grab adalah sebuah aplikasi yang cepat dan pengemudi yang sigap. Sedangkan di Iklan Gojek editing cut to cut nya tidak secepat di iklan Grab. Hal ini memang untuk mendukung suasana mencekam dan menegangkan. Namun di bagian saat dia bergegas lari keluar kantor editing cut to cutnya terlihat lebih cepat. Di sini terlihat ingin menonjolkan keunggulan aplikasi Gojek yang juga cepat dan pengemudinya sigap.

Pada iklan Grab secara visual terlihat berusaha memberikan gambaran mengenai manfaat fitur barunya yaitu pengguna Grab tidak perlu berlama-lama menunggu kedatangan pengemudi Grab sehingga lebih besar kemungkinan bisa cepat tiba di lokasi tujuan. Sedangkan visual di iklan Gojek manfaat yang ditonjolkan adalah fokus bagaimana pengguna tidak perlu lama menunggu bahkan siap di saat sudah larut malam, namun tidak dilanjutkan dengan pesan bahwa akan cepat tiba di lokasi tujuan. Warna yang digunakan di iklan masing-masing ingin menunjang terciptanya gambaran yang memang nyata dirasakan oleh pemirsa. Warna dominan gelap hitam menegaskan suasana mistis yang di kalangan masyarakat Indonesia memang menganggap bahwa di malam hari di tempat gelap dan sepi adalah suasana yang menyeramkan. Sedangkan di iklan Grab warna yang digunakan tidak terlalu mencolok cenderung pudar, Penggunaan warna-warna ini terlihat ingin menampilkan suasana hangat dan rukun (Schemecolor.com, 2021). Sebuah suasana yang akan dengan mudah ditemui di lingkungan rusun dan pemukiman yang rumahnya saling berdekatan. Berbeda dengan suasana tempat tinggal yang eksklusif yang justru sesama warga jarang terjadi interaksi.

\section{KESIMPULAN}

Dari penelitian ini dapat dilihat bagaimana penggambaran konsumen transportasi online dan kehidupan yang dijalaninya digambarkan lewat iklan. Dari analisa di atas dapat disimpulkan bahwa baik Gojek maupun Grab ingin menyampaikan bahwa penumpang akan cepat dijemput. Lalu jika kedua iklan ini dibandingkan maka Gojek dan Grab menghadirkan pesan tambahan yang menjadi pembeda. Gojek menegaskan kelebihan layanan dengan adanya fitur titik jemput. Penyampaian pesan mengenai fitur ini seolah menegaskan bahwa pengemudi Gojek tidak akan kesulitan mencari lokasi jemput karena mengikuti titik. Sedangkan pada Grab sendiri menyampaikan bahwa penumpang tidak hanya cepat dijemput tetapi juga cepat tiba di tujuan. Pada saat memperlihatkan pengemudi, Gojek memperlihatkan bahwa di saat tidak ada orang lain, maka pengemudi Gojek hadir sebagai penyelamat. Sedangkan pada iklan Grab diperlihatkan pengemudi Grab tidak akan kesulitan mendapatkan pengemudi karena armadanya sudah banyak yang standby. 


\section{DAFTAR PUSTAKA}

Berger, A. A. (2018). Media and communication research methods: An introduction to qualitative and quantitative approaches. Sage Publications.

Crow, D. (2011). Visible signs: An introduction to semiotics in the visual arts (Vol. 40). ava publishing.

Grab Indonesia. (2019). Tingkatkan Produktivitas Masyarakat, GrabBike Berikan Dukungan bagi Para Pejuang \#AntiNgaret di Indonesia. Retrieved August 31, 2021, from https://www.grab.com/id/en/press/tech-product/tingkatkanproduktivitas-masyarakat-grabbike-berikan-dukungan-bagi-para-pejuangantingaret-di-indonesia/

Hood, B. H. (2014). Semiotik \& dinamika sosial budaya. Komunitas Bambu, Depok.

Khamadi, K., \& Senoprabowo, A. (2018). Adaptasi Permainan Tradisional Mul-Mulan ke dalam Perancangan Game Design Document. ANDHARUPA: Jurnal Desain Komunikasi Visual \& Multimedia, 4(1), 100-118.

Khamadi, \& Senoprabowo, A. (2021). Pengembangan Desain Karakter Komik Warak Ngendog Berbasis Nilai-Nilai Kearifan Lokal. Jurnal Bahasa Rupa, 4(2), 186-195.

Muqoddas, A., \& Hasyim, N. (2016). Representasi Anti Diskriminasi pada Film Kartun 3D Zootopia (Kajian Semiotika Roland Barthes). ANDHARUPA: Jurnal Desain Komunikasi Visual \& Multimedia, 2(2), 151-166.

Rose, G. (2016). Visual methodologies: An introduction to researching with visual materials. sage.

Schemecolor.com. (2021). Dull Color Combinations " SchemeColor.com. Retrieved August 31, 2021, from https://www.schemecolor.com/color/dull-colorschemes

Shimp, T. A. (2003). Periklanan promosi \& aspek tambahan komunikasi. Pemasaran. Terpadu, Jilid I (Edisi 5), Jakarta: Erlangga.

Subarkah, T. (2019). Gojek Luncurkan Kampanye \#GakPakeLama. Retrieved August 31, 2021, from Media Indonesia website: https://mediaindonesia.com/megapolitan/265508/gojek-luncurkankampanye-gakpakelama

Sulistiyawati, P. (2016). Analisis Semiotika Makna Pesan pada Iklan Axis Versi "Iritologi Menatap Masa Depan." ANDHARUPA: Jurnal Desain Komunikasi Visual \& Multimedia, 2(1), 88-102.

Suryaningtyas, V. W., Nugroho, R. A., Cahyono, S. P., Nababan, M. R., \& Santosa, R. (2019). Evaluasi Apraisal Teks dan Semiotika Visual Pada Brosur Promosi Daerah Tujuan Wisata Bilingual. ANDHARUPA: Jurnal Desain Komunikasi Visual \& Multimedia, 5(2), 187-209. 